\title{
The Effects of Hypophysectomy on the Digestive Glands of the Mouse ${ }^{1}$
}

\author{
RICHARD MORTSON KOERKER 2 \\ Department of Anatomy, The University of Michigan \\ Medical School, Ann Arbor, Michigan
}

\begin{abstract}
The objective was to observe the influence of hypophysectomy on the secretory cells of digestive glands in the mouse and to compare these findings with those reported for other mammalian species. Hypophysectomy of the mouse induced involutional changes in glandular cells concerned with secretion of proteins and mucins, and in those involved in ion transport or release. Gastric chief cells, pancreatic acinar cells, and serous cells of submandibular tubules were markedly involuted; acinar cells of the parotid gland were changed less significantly. Gastric mucous neck cells and mucous acinar cells of the submandibular and sublingual glands contained less secretory material. A colloidal iron-positive variety of mucous neck cell became dominant. These changes were less profound than those which occurred in most types of zymogenic cells. Parietal cells became atrophic and contained a greatly contracted intracellular canalicular system. Salivary ducts of the parotid and sublingual glands showed partial involution. It was concluded that, as in the rat and man, proteinsecreting cells of the digestive tract of the mouse depend on the support of pituitary hormones. Those cells which secrete mucopolysaccharides or are involved in ion transport also require pituitary hormones for complete maintenance of their structure and function.
\end{abstract}

Schooley, Riddle and Bates ('41) first demonstrated that the pituitary gland influences the digestive system, by observing a loss in weight of the gastrointestinal tract in the pigeon after hypophysectomy. More recently, others have shown that the hypophysis exerts significant control over the structure and function of digestive glands in the rat. Thus, all zymogenic cells which have been studied are dependent on the support of pituitary and other hormones for maintenance of normal structure and full secretory activity. These include the gastric chief cell (Baker and Abrams, '54), acinar cells of the pancreas (Haist, '55) and parotid gland (Baker and Abrams, '55), zymogenic cells of the submandibular serous ducts (Lacassagne and Chamorro, '40) and cells of Paneth in the intestine (Baker et al., '58). In addition, mild structural involution (Baker and Abrams, '54; Baker and Clark, '61) and functional depression (Crafts and Walker, '47) take place in the gastric parietal cells after pituitary ablation.

In contrast to the rather detailed information available concerning the action of hormones on the digestive glands of the rat, relatively little is known about their effects in other mammals. Investigations carried out on the stomach indicate that regressive changes occur during pituitary deficiency in the cat (Cutting et al., '37; Haeger et al., '53) and man (Laumonier et al., '63; Dotevall and Westling, '63). In this report, the influence of hypophysectomy on the histology and histochemistry of the gastric mucosa, pancreas and parotid, submandibular and sublingual glands of the mouse will be described. Such information will help to indicate the extent to which digestive glands of mammals in general are dependent on hormonal stimulation.

\section{MATERIALS AND METHODS}

The experiments were carried out on young adult male ICR Swiss mice. Hypophysectomy was performed by the transauricular method of Falconi and Rossi ('64). Completeness of hypophysectomy was verified by histological observation of serial sections of the pituitary region. Incompletely hypophysectomized mice were discarded. A nonhypophysectomized mouse

\footnotetext{
1 Supported in part by research grant AM 00131-14 from the United States Public Health Service.

2 From a dissertation submitted in partial fulfulment of the requirements for the Doctor of Philosophy
} degree. 
was retained as a control for each hypophysectomized animal.

The mice were fed a diet consisting of Purina mouse breeder chow supplemented with lettuce, bread and cod-liver oil. In order to evaluate the influence of food intake on the results obtained, the animals were arranged in two experiments. In Experiment I, 11 hypophysectomized mice and 18 controls were allowed to eat ad libitum. In Experiment II, each of 12 nonhypophysectomized control mice was pairfed against a hypophysectomized animal so that the control received the amount of food eaten by its operated mate on the previous day. During the first seven days of this experiment the mice were not paired, but the operated animals were fed daily the average amount of food consumed by hypophysectomized mice as determined by previous observations. Each hypophysectomized mouse was kept in the same cage as its pair-fed control, the two mice being separated by a screen. Since ingestion of food elicits structural changes in the digestive glands, the animals were starved for 8-12 hours before being killed. This was shown to be the optimal starvation time by preliminary experiments. Practically complete degranulation occurred in both the parotid gland and pancreas of some control mice if more than a 12-hour starvation time was employed.

When 8-10 weeks had elapsed after hypophysectomy, the stomach, pancreas and salivary glands were removed while the animals were under sodium amytal anesthesia. The organs were dissected free of contiguous tissue and weighed. The following procedure was developed to make possible a clean excision of the parotid gland so that reproducible weights could be obtained. The cervical skin with parotid gland attached was stretched by grasping it between the thumb and index finger and then pulling it over the index finger. The outline of the parotid gland was clearly visible, and the gland could be freed from the connective tissue. Histological sections showed that minimal fat and connective tissue were retained.

The following fixatives were used for the purposes and times indicated: formalinalcohol-acetic acid (FAA) (48 hours at $4^{\circ} \mathrm{C}$ ) for the demonstration of ribonucleo- protein, mucoprotein and glycogen; Champy's fluid ( 24 hours) and post-osmication for three days at $37^{\circ} \mathrm{C}$ for the Golgi apparatus; Regaud's fluid ( 96 hours) for mitochondria; Zenker-formol ( 5 hours) for ribonucleic acid (RNA) and mitochondria; and Bouin's fluid ( 24 hours) for general tissue structure. The extent to which each fixative was used is summarized in table 1. Some stomachs were injected with fixative to effect uniform distension of the organ and, thus, permit accurate observation of change in mucosal thickness. Areas of mucosa along the greater curvature were used for study. Tissues fixed in Regaud's fluid or Zenker-formol were post-chromated in $3 \%$ potassium dichromate for three days. After embedding in either paraffin or celloidin and paraffin, sections were cut at 3-5 $\mu$.

A variety of staining procedures (table 1) were employed for the following purposes. Hematoxylin-Masson was used to reveal general tissue structure, azure II for cytoplasmic and nuclear basophilia, periodic acid-Schiff (PAS) (Hotchkiss, ${ }^{4} 48$ ) for neutral mucopolysaccharides, colloidal iron (Rinehart and Abul-Haj, '51) for acid mucopolysaccharides, and PAS-colloidal iron (Mowry, '58) to differentiate acid from neutral mucopolysaccharides. Certain slides were digested with a buffered a-amylase or in buffer alone before staining with PAS as a control for the demonstration of glycogen. For study of mitochondria, tissues fixed in Regaud's, Champy's or Zenker-formol fixatives were stained with the Altmann-Masson procedure (Severinghaus and Thompson, '39).

The significance of the differences between quantitative data for control and hypophysectomized groups was determined by the Wilcoxon two sample test (Steel and Torrie, '60). Significance was attributed to differences with less than a 5\% probability of error.

\section{OBSERVATIONS}

Hypophysectomized mice lost weight after the operation (table 2). The body weight of pair-fed control mice showed little change (Experiment II, table 2). The control mice (Experiment I) which ate ad libitum continued to gain in weight. The histology of digestive glands in the pair-fed 
TABLE 1

Summary of distribution of animals and technical methods used

\begin{tabular}{|c|c|c|c|c|c|}
\hline \multicolumn{4}{|c|}{ Number of mice } & \multirow{2}{*}{\multicolumn{2}{|c|}{ Technical methods }} \\
\hline \multicolumn{2}{|c|}{ Experiment I } & \multicolumn{2}{|c|}{ Experiment II } & & \\
\hline Hyp. & Control & Hyp. & Control & Fixation & Stain \\
\hline \multicolumn{6}{|c|}{ Stomach } \\
\hline $\begin{array}{r}11 \\
7 \\
4 \\
7\end{array}$ & $\begin{array}{r}18 \\
9 \\
8 \\
14\end{array}$ & $\begin{array}{l}12 \\
12 \\
12 \\
12\end{array}$ & $\begin{array}{r}12 \\
12 \\
12 \\
8\end{array}$ & $\begin{array}{l}\text { FAA } 1 \\
\text { FAA } \\
\text { FAA } \\
\text { Regaud's fluid }\end{array}$ & $\begin{array}{l}\text { PAS 2-azure II, colloidal iron-PAS } \\
\text { Colloidal iron } \\
\text { a-Amylase digestion; PAS } \\
\text { Altmann-Masson }\end{array}$ \\
\hline 10 & 18 & 12 & 12 & $\begin{array}{l}\text { Pancreas } \\
\text { Bouin's }\end{array}$ & $\begin{array}{l}\text { Hematoxylin-Masson; azure II- } \\
\text { eosin }\end{array}$ \\
\hline 7 & 14 & 10 & 12 & Zenker-formol & $\begin{array}{l}\text { Azure II-phloxine; Altmann- } \\
\text { Masson }\end{array}$ \\
\hline $\begin{array}{l}4 \\
3\end{array}$ & $\begin{array}{l}7 \\
4\end{array}$ & $\begin{array}{l}6 \\
5\end{array}$ & $\begin{array}{l}6 \\
3\end{array}$ & $\begin{array}{l}\text { Champy's fluid } \\
\text { Champy's fluid }\end{array}$ & $\begin{array}{l}\text { Altmann-Masson } \\
\text { Post-osmication }\end{array}$ \\
\hline \multicolumn{6}{|c|}{ Salivary glands } \\
\hline 11 & 17 & 12 & 12 & FAA & $\begin{array}{l}\text { PAS-azure II; colloidal iron; } \\
\text { colloidal iron-PAS }\end{array}$ \\
\hline $\begin{array}{l}2 \\
7\end{array}$ & $\begin{array}{r}6 \\
14\end{array}$ & $\begin{array}{r}5 \\
10\end{array}$ & $\begin{array}{r}3 \\
11\end{array}$ & $\begin{array}{l}\text { FAA } \\
\text { Zenker-formol }\end{array}$ & $\begin{array}{l}\text { a-Amylase digestion; PAS } \\
\text { Altmann-Masson }\end{array}$ \\
\hline
\end{tabular}

Hyp. = hypophysectomized.

FAA $=$ formalin-alcohol-acetic acid.

PAS = periodic acid-Schiff.

TABLE 2

The effect of hypophysectomy on weights of the body and stomach

\begin{tabular}{|c|c|c|c|c|c|}
\hline \multirow{3}{*}{ Treatment } & \multirow{3}{*}{$\begin{array}{l}\text { No. of } \\
\text { mice }\end{array}$} & \multirow{2}{*}{\multicolumn{2}{|c|}{ Body weight (g) }} & \multicolumn{2}{|c|}{ Stomach } \\
\hline & & & & \multirow[b]{2}{*}{ Weight (mg) } & \multirow{2}{*}{$\begin{array}{c}\text { Organ wt. (mg) } \\
\begin{array}{c}\text { Body wt. }(\mathrm{g}) \\
\times 10,000\end{array}\end{array}$} \\
\hline & & Initial & Final & & \\
\hline \multicolumn{6}{|c|}{ Experiment I Ad libitum-fed } \\
\hline $\begin{array}{l}\text { Control } \\
\text { Hyp. }\end{array}$ & $\begin{array}{l}18 \\
11\end{array}$ & $\begin{array}{c}23.9 \pm 0.9^{1} \\
23.1 \pm 0.4 \\
\mathbf{P}\end{array}$ & $\begin{array}{c}33.1 \pm 0.5 \\
18.8 \pm 0.5 \\
<0.01\end{array}$ & $\begin{array}{l}230.2 \pm 17.7^{2} \\
138.5 \pm 9.9^{3} \\
<0.01\end{array}$ & $\begin{array}{l}69.1 \pm 5.0 \\
75.5 \pm 5.5 \\
\text { NS }\end{array}$ \\
\hline \multicolumn{6}{|c|}{ Experiment II Pair-fed } \\
\hline $\begin{array}{l}\text { Control } \\
\text { Hyp. }\end{array}$ & $\begin{array}{l}12 \\
12\end{array}$ & $\begin{array}{r}25.9 \pm 1.4 \\
23.7 \pm 1.1 \\
P\end{array}$ & $\begin{array}{c}24.7 \pm 1.2 \\
19.4 \pm 0.6 \\
<0.01\end{array}$ & $\begin{array}{c}275.7 \pm 15.0 \\
154.9 \pm 7.1 \\
<0.01\end{array}$ & $\begin{array}{c}112.6 \pm 5.1 \\
80.2 \pm 3.5 \\
<0.01\end{array}$ \\
\hline \multicolumn{3}{|c|}{ Control Exp. I vs. Control Exp. II } & & NS & $<0.01$ \\
\hline
\end{tabular}

Hyp. = hypophysectomized; $\mathrm{P}=$ probability of error; $\mathrm{NS}=$ not significantly different at $\mathrm{P}<0.05$.

1 Standard error of the mean.

2 Ten mice.

Six mice.

control mice did not differ from that of the ad libitum-fed controls, except for the pancreas and submandibular gland. Pancreatic acini were smaller and the serous tubules of the submandibular gland were reduced in diameter as a result of pairfeeding. Generally, no other histological effects were noted which could be attributed to food restriction. Therefore, the effects of hypophysectomy as described in the following account apply to both experiments unless stated to the contrary.

With respect to the normal structure of the stomach, pancreas and salivary glands in the mouse, this presentation will be concerned only with those observations which have not been previously reported. The histology of these glands has been de- 
scribed by Fekete ('41). Additional information on the submandibular gland was presented by Lacassagne ('40), Junqueira ('64), Junqueira et al. ('49), Raynaud ('60) and Schätzle ('62). The histochemistry of mucins in the submandibular and sublingual glands and stomach was analyzed by spicer ('60) and Spicer and Jarrels ('61). Parks ('61) reported on the histology and ultrastructure of the parotid gland.

\section{The stomach}

Control mice. The difference between the mean stomach weights of the ad libitum- and pair-fed controls was not significant (table 2) but between the mean organ weight/body weight ratios the difference was significant $(P<0.01)$. Thus absolute weight of the stomach appears to be unaffected by reduced food intake.

Mucous neck cells were interposed among the parietal cells in the area of the mucosa just above the chief cells (fig. 1). In FAA-fixed material, three histochemically different varieties of mucous neck cells were observed in stomachs stained with colloidal iron-PAS (fig. 3). To one group of mucous neck cells, colloidal iron imparted an aquamarine color. The stained material was in the form of tightly packed granules. The cytoplasm of a second group of mucous neck cells stained red with PAS. The third group contained both PASpositive cytoplasm and colloidal iron-positive granules. In an individual stomach, the colloidal iron-positive cells were usually smaller than the PAS-positive cells. Cells containing both PAS- and colloidal ironpositive material varied in size. All three varieties were present in a single animal, usually within a single fundic gland, and one variety was numerically dominant. No single varety was consistently dominant in all control animals.

When PAS staining was used after FAA fixation, the cytoplasm of parietal cells stained pink and had a mottled appearance. Mucoprotein, which appeared to be associated with the microvilli of intracellular canaliculi, stained more intensely, creating a perinuclear halo of PAS-positive material (fig. 5). The PAS-positive material was not glycogen, as indicated by its resistance to digestion with $\alpha$-amylase, nor was it an acid mucopolysaccharide, since it did not stain with colloidal iron. Large rounded mitochondria were found everywhere in the cytoplasm except in that area occupied by intracellular canaliculi (fig. 7). Thus, mitochondria were arranged in two rings, one surrounding the nuclear membrane and the other being situated inside the plasmalemma. The zone between these rings of mitochondria coincided with the position of intracellular canaliculi as indicated by the PAS-positive halo.

In addition to the basally located cytoplasmic basophilia of chief cells, a fine network of basophilic material outlined the secretory granules (fig. 11). The long, thread-like mitochondria of chief cells (fig. 9) were oriented randomly in the subnuclear region and vertically in the area lateral to the nucleus. Chief cell nuclei contained large nucleoli and fine chromatin material.

Hypophysectomized mice. In both experiments, the weight of the stomach was less in hypophysectomized than in control mice (table 2). These differences, when considered as absolute values or in relation to body weight (except in Experiment I), were significant at less than the $1 \%$ level of confidence, which indicated that the stomach may be more sensitive to hormonal withdrawal than the body as a whole. The results in Experiment II also demonstrate that the reduction in stomach weight after pituitary excision is not due to reduced food intake.

The fundic mucosa in hypophysectomized mice was thinner than in the controls (fig. 2). The lumina of the fundic glands were often enlarged as compared with control mice, in which they were seldom visible in microscopic sections. Dilation of the fundic lumina appeared more pronounced after fixation in Regaud's fluid than in FAA. It was most prominent in the middle one-third of the mucosa (parietal cell area) (figs. 6, 8) and less so in the base of the fundic gland.

Although no changes were observed in surface and nondifferentiated cells, mucous neck cells were altered by pituitary excision. The number of mucous neck cells per fundic gland appeared to be increased in hypophysectomized mice. The cells were usually smaller than those of controls and 
contained less secretory material (fig. 4). In 21 of 22 animals, the colloidal ironpositive variety of mucous neck cell was dominant, and only rarely were the other varieties seen. Transitional cells containing both PAS-positive and colloidal ironpositive material were dominant in the one exceptional case. The nucleus and mitochondria were unchanged.

After hypophysectomy, the number of parietal cells per fundic gland appeared to be unchanged, but they were strikingly atrophic (figs. 4,6, 8). The cytoplasm maintained a pink mottled appearance with PAS staining. The perinuclear halo, which in controls marked the location of intracellular canaliculi, was no longer present. Rather, the PAS-positive material was arranged as a dense clump on the luminal side of the nucleus which indicated that a profound alteration had occurred in the structure of the intracellular canaliculi. This conclusion was confirmed by observation of stomachs fixed in Regaud's fluid and stained with the Altmann-Masson procedure (fig. 8 ). In them, the canaliculi also seemed to be restricted to the luminal side of the nucleus. Thus, the intracellular canaliculi, which in controls cupped around the nucleus from its luminal side and extended into the basal region of the parietal cell, were reduced to a small area between the nucleus and the glandular lumen. Consequently, instead of forming two distinctly separate perinuclear rings, mitochondria filled the entire cytoplasmic area basal and lateral to the nucleus (fig. 8 ) in parietal cells of hypophysectomized mice. The total number of mitochondria was reduced. Atrophy of the parietal cells appeared to be partly responsible for the increased caliber of the glandular lumen. Nuclear size was slightly decreased and chromatin usually appeared more compact.

Chief cells appeared to be reduced in number per fundic gland and were remarkably involuted (fig. 2), being changed from the high columnar form characteristic of the controls (fig. 11) to a low cuboidal shape (fig. 12). Fewer secretory granules were present per cell and the expansive, granule-filled apical area seen in control animals had disappeared. In some hypophysectomized mice, chief cells had no visible granules at all. The total amount of basophilic material and the intensity of staining with azure II were reduced. Mitochondria were shorter, wider and fewer in number (figs. 9, 10). Chromatin was more compact. In 17 of 22 operated mice, nucleoli were smaller than in the controls.

\section{The pancreas}

Control mice. The diameter of pancreatic acini of pair-fed controls was somewhat less than that of ad libitum-fed control mice, although glandular weights and gland weight/body weight ratios were not different in the two groups (table 3 ).

For study of the size, number and distribution of organelles, employment of several procedures was necessary. Secretory granules were not preserved consistently by Bouin's fluid but, after fixation in Champy's fluid or Zenker-formol followed by Altmann-Masson staining, they appeared intensely and uniformly stained (fig. 15). Cells in acini adjacent to pancreatic islets were usually filled with granules, while in other areas of the gland the storage of granules varied from acinus to acinus. Evaluation of the amount of cytoplasmic basophilia in pancreatic acinar cells was difficult since the distribution of basophilic material was affected by the number of secretory granules. It was concentrated basally in granule-filled cells and arranged more diffusely in granule-poor cells. A fine network of basophilic material consistently surrounded the secretory granules (fig. 13). Mitochondria appeared as darkly stained threads of varied thickness and length (fig. 15). They were most numerous beneath the nucleus and were arranged with their long axes parallel to the base of the cell; laterally they were oriented perpendicular to the base of the cell. The Golgi apparatus (fig. 17) consisted of a reticular network located above the nucleus and dispersed among the supranuclear secretory granules. Large nuclei with chromatin clumped along the nuclear membrane and with large, irregularly shaped nucleoli were seen in ad libitum-fed controls. In contrast, nucleoli of pair-fed controls (fig. 13) were somewhat smaller and rounder.

Hypophysectomized mice. Hypophysectomy caused involution of the pancreas as shown by its lower absolute weight in hypophysectomized mice of both experiments 
TABLE 3

The effect of hypophysectomy on weights of the pancreas and parotid gland

\begin{tabular}{|c|c|c|c|c|c|c|}
\hline \multirow{3}{*}{ Treatment } & \multirow{3}{*}{$\begin{array}{c}\text { No. of } \\
\text { mice }\end{array}$} & & \multicolumn{2}{|c|}{ Pancreas } & \multicolumn{2}{|c|}{ Paratid gland } \\
\hline & & & \multirow[b]{2}{*}{ Weight (mg) } & \multirow{2}{*}{$\begin{array}{c}\text { Gland wt. (mg) } \\
\begin{array}{c}\text { Body wt. (g) } \\
\times 10,000\end{array}\end{array}$} & \multirow[b]{2}{*}{ Weight (mg) } & \multirow{2}{*}{$\begin{array}{c}\text { Gland wt. (mg) } \\
\text { Body wt. (g) } \\
\times 10,000\end{array}$} \\
\hline & & & & & & \\
\hline & & & Experiment I & Ad libitum-fed & & \\
\hline $\begin{array}{l}\text { Control } \\
\text { Hyp. }\end{array}$ & $\begin{array}{l}18 \\
11\end{array}$ & $\mathbf{P}$ & $\begin{array}{c}291.3 \pm 30.2 \\
115.0 \pm 13.7 \\
<0.01\end{array}$ & $\begin{array}{c}87.9 \pm 9.0 \\
60.5 \pm 6.7 \\
<0.05\end{array}$ & $\begin{array}{c}26.8 \pm 1.5^{2} \\
16.1 \pm 1.4^{3} \\
<0.01\end{array}$ & $\begin{array}{l}8.1 \pm 0.6 \\
9.0 \pm 0.5 \\
\text { NS }\end{array}$ \\
\hline \multicolumn{7}{|c|}{ Experiment II Pair-fed } \\
\hline $\begin{array}{l}\text { Control } \\
\text { Hyp. }\end{array}$ & $\begin{array}{l}12 \\
12\end{array}$ & $\mathbf{P}$ & $\begin{array}{c}231.7 \pm 18.4 \\
167.3 \pm 19.6 \\
<0.01\end{array}$ & $\begin{array}{c}92.8 \pm 4.5 \\
85.3 \pm 9.0 \\
\text { NS }\end{array}$ & $\begin{array}{c}26.0 \pm 1.7^{4} \\
16.9 \pm 0.9^{4} \\
<0.01\end{array}$ & $\begin{array}{c}10.9 \pm 1.1 \\
9.2 \pm 0.6 \\
\text { NS }\end{array}$ \\
\hline $\begin{array}{l}\text { Control I vs. } \\
\text { Control II }\end{array}$ & & $\mathbf{P}$ & NS & NS & NS & $<0.05$ \\
\hline
\end{tabular}

Hyp $=$ hypophysectomized; $P=$ probability of error; $N S=$ not significantly different at $P<0.05$.

1 Standard error of the mean.

2 Eight mice.

3 Four mice.

4 Six mice.

(table 3) as compared with the controls. In only Experiment I, was the mean gland weight/body weight ratio reduced.

Loss of weight of the pancreas was reflected in its histology. Acinar diameter and cell size were less in hypophysectomized mice when compared with both ad libitum-fed and pair-fed controls (figs. 14, 16). Although much less numerous, the number of secretory granules was more uniform among the acinar cells of hypophysectomized mice than of controls. The peri-islet acinar cells showed less degranulation than other acinar cells. Cytoplasmic basophilic material was reduced in amount and less intensely stained both basally and between the secretory granules. Mitochondria were thinner and shorter (fig. 16). The Golgi apparatus was condensed into a compact supranuclear body (fig. 18). Nuclei and nucleoli were often smaller and the chromatin was more compactly arranged.

\section{The parotid gland}

Control mice. The absolute weight of the parotid gland was not affected by pair-feeding but the difference between the mean gland weight/body weight ratios of pair-fed and ad libitum-fed controls was significant (table 3 ).

Acinar cells of the parotid gland were pyramidal and contained basal cytoplasmic basophilic material (fig. 24) which ex- tended as a fine network among the apical secretory granules. Mitochondria were short rods and were randomly oriented in the basal half of the acinar cell (fig. 19). Epithelial cells lining salivary ducts were columnar, lightly PAS-positive and possessed basal striations (figs. 22, 24). Most mitochondria were located in the basal area of the cell and arranged parallel to the basal striations; a few were scattered in the apical cytoplasm. They were long and thin (fig. 20). The cells lining the intercalated ducts were low cuboidal and possessed a small area of cytoplasmic basophilia on either side of the nucleus. The background cytoplasm stained rose with PAS and sometimes contained PASpositive granules. These granules were not glycogen, since digestion with a-amylase did not remove them.

Hypophysectomized mice. The mean weight of the parotid gland was reduced after hypophysectomy (table 3 ). However, the mean gland weight/body weight ratio remained unchanged.

Histological changes induced in the parotid gland by hypophysectomy were similar to, but not as great as, those elicited in the pancreas. Parotid acini were smaller (fig. 23), the epithelial cells being reduced in size and containing fewer secretory granules (fig. 25) than those of controls. Basophilia was absent from the apical granulated region and was reduced 
basally in 13 of 22 hypophysectomized mice (fig. 25). However, the decrease in basophilia was less pronounced than in the other glands studied. Mitochondria were thinner and appeared to be more concentrated due to the loss of intervening secretory granules (fig. 21). Nuclei and nucleoli were unchanged.

The duct system of the parotid gland was also affected by hypohysectomy. The diameter of salivary ducts and size of their lining cells were reduced (fig. 21). Basal striations were no longer visible (fig. 25). Mitochondria in the subnuclear region were shorter, randomly oriented and more densely packed than in controls. Cells lining the intercalated ducts were less basophilic but their PAS-positive granules were unaffected.

\section{The submandibular gland}

Control mice. The submandibular glands of pair-fed control mice weighed less than those of ad libitum-fed controls $(P<0.01)$ but the means of the gland weight/body weight ratios for the two control groups did not differ significantly (table 4). Thus, with respect to weights, the submandibular gland and body responded to restricted food intake in parallel fashion.

The diameter of the submandibular serous tubules in paired-fed control mice was less than that of the ad libitum-fed controls. The large granules in the apical half of the serous tubular cells stained with the Altmann-Masson procedure (fig. 30). A diffuse cytoplasmic basophilia was present in the basal area (fig. 28), where the mitochondria seemed to be compressed by the accumulated serous granules (fig. 30 ). In partly degranulated cells some mitochondria were visible in the supranuclear zone. Mitochondria were randomly oriented and, when cut longitudinally, appeared as short rods.

Acinar cells of the submandibular gland were filled with mucous secretory material. Cytoplasmic basophilia was most dense in the basal area (fig. 28, inset) but occurred elsewhere in the cytoplasm also. When stained with colloidal iron-PAS, the mucous secretion appeared dark blue (fig. 26).

Hypophysectomized mice. The mean weight of the submandibular gland in hypophysectomized mice and the mean gland weight/body weight ratios were reduced $(P<0.01)$ (table 4$)$. The effect of hypophysectomy on the histology of the submandibular gland of the mouse has been described by Lacassagne and Chamorro ('40), and Shafer and Muhler ('60).

As noted by these workers, the marked atrophy of the serous tubules, with a loss of serous granules (figs. 27, 31) and cytoplasmic basophilia and a decrease in nuclear size (fig. 29) were observed. The following new observations were made. A chronic sialitis was often present after hypophysectomy. Glycogen granules became more prevalent in the apical region of serous tubular cells. Mitochondria were more fre-

TABLE 4

The effect of hypophysectomy on weights of the submandibular and sublingual glands

\begin{tabular}{|c|c|c|c|c|c|c|}
\hline \multirow{3}{*}{ Treatment } & \multirow{3}{*}{$\begin{array}{l}\text { No. of } \\
\text { mice }\end{array}$} & & \multicolumn{2}{|c|}{ Submandibular gland } & \multicolumn{2}{|c|}{ Sublingual gland } \\
\hline & & & \multirow[b]{2}{*}{ Weight (mg) } & \multirow{2}{*}{$\begin{array}{c}\text { Gland wt. (mg) } \\
\text { Body wt. (g) } \\
\times 10,000\end{array}$} & \multirow[b]{2}{*}{ Weight (mg) } & \multirow{2}{*}{$\begin{array}{c}\text { Gland wt. (mg) } \\
\begin{array}{c}\text { Body wt. (g) } \\
\times 10,000\end{array}\end{array}$} \\
\hline & & & & & & \\
\hline & & & Experiment I & Ad libitum-fed & & \\
\hline $\begin{array}{l}\text { Control } \\
\text { Hyp. }\end{array}$ & $\begin{array}{l}18 \\
11\end{array}$ & $\mathbf{P}$ & $\begin{array}{c}83.5 \pm 3.1^{1} \\
17.4 \pm 0.7 \\
<0.01\end{array}$ & $\begin{array}{c}25.0 \pm 0.8 \\
9.2 \pm 0.4 \\
<0.01\end{array}$ & $\begin{array}{c}10.7 \pm 0.5 \\
5.9 \pm 0.2 \\
<0.01\end{array}$ & $\begin{array}{c}3.2 \pm 0.2 \\
3.1 \pm 0.2 \\
\text { NS }\end{array}$ \\
\hline \multicolumn{7}{|c|}{ Experiment II Pair-fed } \\
\hline $\begin{array}{l}\text { Control } \\
\text { Hyp. }\end{array}$ & $\begin{array}{l}12 \\
12\end{array}$ & $\mathbf{P}$ & $\begin{array}{c}57.2 \pm 4.7 \\
19.6 \pm 1.1 \\
<0.01\end{array}$ & $\begin{array}{c}22.8 \pm 1.1 \\
10.1 \pm 0.5 \\
<0.01\end{array}$ & $\begin{array}{c}12.1 \pm 0.7 \\
8.4 \pm 0.5 \\
<0.01\end{array}$ & $\begin{array}{c}4.9 \pm 0.2 \\
4.3 \pm 0.3 \\
\mathrm{NS}\end{array}$ \\
\hline \multicolumn{2}{|c|}{$\begin{array}{l}\text { Control Exp. I vs. } \\
\text { Control Exp. II }\end{array}$} & $\mathbf{P}$ & $<0.01$ & NS & NS & $<0.01$ \\
\hline
\end{tabular}

Hyp. = hypophysectomized; $P=$ probability of error; $N S=$ not significantly different at $P<0.05$.

I Standard error of the mean. 
quently arranged perpendicular to the base of the serous tubular cells (fig. 31). The smaller diameter of the involuted serous ducts and their more numerous intracellular PAS-positive granules (fig. 29) were the only features which enabled one to differentiate them from the nonserous portions of the intralobular duct system.

In addition to the reported atrophy of serous tubules, mucous acini (figs. 27, 29) were reduced in diameter and their epithelial cells were smaller in hypophysectomized mice than in controls. PAS-positive material was decreased in total amount, less intensely stained and had a foamy appearance in contrast to the granular form characteristic of the mucin in most acini of controls. The colloidal iron-PAS procedure revealed the secretory material to be aqua-green (fig. 27), in contrast to its blue color in acinar cells of control mice. Cytoplasmic basophilia was somewhat reruced in total amount and staining intensity (fig. 29). Nuclei of mucous cells appeared slightly smaller but nucleoli were unchanged. Intercalated ducts were unaltered, even though they appeared more prominent because of the acinar involution.

The sublingual gland

Control mice. As compared with ad libitum feeding, restriction of food intake by pair-feeding did not affect the weight of the sublingual glands but increased the mean gland weight/body weight ratio ( $P$ $<0.01$ ) (table 4). The change in the latter value reflects considerable loss in body weight without a comparable reduction in weight of the gland.

The secretory material of mucous acinar cells (fig. 32) had a foamy appearance when stained with PAS. With combined colloidal iron and PAS, material staining with PAS was found in the apical part of the cell while other regions reacted intensely to colloidal iron. The nucleus was displaced basally by the accumulated intracellular secretion and basophilic material was scattered in the cytoplasm around it.

Epithelial cells of the salivary ducts in control animals had prominent basal striations (fig. 34) which stained with colloidal iron (fig. 36). In 6 of 21 animals, scattered cells of the salivary ducts were filled with granules (Spicer and Jarrels, '61) which did not react with either PAS or colloidal iron, but stained intensely with the Altmann-Masson procedure (fig. 34). These granules were of the same size and staining properties as those of the serous tubules found in the submandibular gland. Mitochondria (fig. 34) were distributed along the basal striations and scattered throughout the cytoplasm of the duct cells.

Hypophysectomized mice. The mean absolute weight of the sublingual gland was reduced in hypophysectomized mice $(\mathrm{P}<0.01$ ) (table 4$)$ but the mean gland weight/body weight ratios were unaffected. Thus, the sublingual gland was no more sensitive to withdrawal of pituitary hormones than was the body as a whole. Histologically, the acinar diameter (figs. 33,35 ) was reduced and acinar cells contained less secretory material. The staining properties of the intracellular mucin, cytoplasmic RNA, nuclei, nucleoli and mitochondria were not changed. Salivary ducts were narrower (fig. 35) and the granulated cells had disappeared. Epithelial cells of salivary ducts were lower and their basal regions contained a few vacuoles (fig. 37) and less distinct basal striations. Mitochondria were shorter, smaller (fig. 35) and no longer arranged between basal striations as in the controls. Nuclei contained clumped chromatin, and nucleoli were less distinct. Intercalated ducts became relatively more prominent after hypophysectomy due to involution of the acini.

\section{DISCUSSION}

\section{Normal histology of the mouse digestive system}

The digestive glands of the normal mouse differ histologically from those of other mammals in several ways. Although mucous neck cells have been demonstrated in several mammalian species, Lillibridge ('64) and Helander ('62, '64) were unable to identify them in man and mouse, respectively, by means of electron microscopy. In agreement with Fekete ('41), my observations reveal the presence of mucous neck cells in the mouse. As compared with their superficial position in the gastric mucosa of most mammals, in the 
mouse they are located in the deeper onethird of the mucosa. Since Helander ('64) could not differentiate mucous neck cells from surface cells in the fundic mucosa of the mouse with the electron microscope, the blue color imparted to mucous neck cells by colloidal iron, as contrasted with the purple color of the surface mucous cells, indicates that they are a unique cell type. The three histochemically different varieties of normal mucous neck cells have not been observed previously. Whether they represent different functional types, different stages in a secretory process, or indicate transformation of one distinct type into a second is not now clear. Spicer ('60) was unable to demonstrate acid radicals in the mucopolysaccharide in mucous neck cells of the mouse without prior chemical treatment, but the intense stain imparted to their intracellular granules by colloidal iron indicates clearly that acid mucopolysaccharides are present.

The perinuclear halo of PAS-positive material in the parietal cell of the normal mouse stomach, which reveals the position of the intracellular canaliculus, probably results from the presence of mucopolysaccharide on the surface of the canalicular wall. A filamentous coat containing mucopolysaccharide has not been seen with the electron microscope covering the intracanalicular microvilli of parietal cells in several mammalian species (Ito, ' 61 and Ito and Winchester, '63) but Sedar ('65) observed it in the frog.

Comparison of the effects of hypophysectomy in the mouse with other mammals

In most respects, the digestive glands of the mouse resemble those of the rat and other animals in their response to hypophysectomy. However, some endpoints are affected differently in the mouse.

Stomach. Involution of the gastric mucosa appears to be a general characteristic of pituitary deficiency in mammals, having been reported in the cat (Haeger et al., '53), rat (Baker and Abrams, '54; Crean, '63a), and man (Dotevall and Westling, '63). These changes appear also in association with panhypopituitarism in man (Laumonier et al., '63). Similarly, the absence of histological change in the surface mucous cells and nondifferentiated cells after hypophysectomy of the mouse is characteristic of the rat (Baker and Abrams, '54; Corpron, '66). However, some functional depression in mucus production is indicated by its reduced content in the stomach (Robert et al., '66).

Mucous neck cells of the mouse are altered significantly by hypophysectomy, in contrast to the minor changes reported in other animals. The irregular reduction in the amount of mucoid material in individual mucous neck cells is seen with the light microscope in both mouse and rat (Baker and Abrams, '54), although no alteration in ultrastructure was observed by Corpron ('66). Unique to the mouse are the apparent increase in the number of mucous neck cells and the predominance of the colloidal iron-positive variety of mucous neck cell which result from pituitary ablation.

In agreement with Crean's ('63a, b) observations in the rat, the number of parietal cells per fundic gland does not seem to be reduced by hypophysectomy in the mouse. However, their size and structure are altered greatly in the mouse, in contrast to the minor structural changes reported for parietal cells of the rat. Of special significance is the change in canalicular structure, as revealed by two staining procedures. This was not apparent in earlier light microscopic studies of rat gastric mucosa and only slight change in the canalicular microvilli was seen by Corpron ('66) with the electron microscope. It is probable that cytological alteration of comparable degree has not been induced previously in the parietal cells of any animal by experimental manipulation. Although some workers (Vial and Orrego, '60; Sedar and Friedman, '61) have reported ultrastructural change in parietal cells after stimulation, Ito ('61) claimed that the form of intracellular canaliculi cannot be used as an index of physiological state because of its extreme normal variation.

The decreases in size of chief cells and their nuclei, in the number of pepsinogen granules and mitochondria, and in cytoplasmic basophilia after pituitary ablation of the mouse are identical with the changes observed in the hypophysectomized rat 
(Baker and Abrams, '54) and similar to those occurring in human panhypopituitarism (Laumonier et al., '63). Corpron ('66) verified these results in the rat with the electron microscope.

Pancreas. The pancreas of the mouse undergoes the same changes after hypophysectomy as seen in other animals. These include loss in weight as observed in the dog (Koster, '30), pigeon (Schooley et al., '41) and rat (Haist, '55), and decreases in acinar diameter, acinar cell size, number of secretory granules, amount of cytoplasmic RNA, number and size of mitochondria, and in nuclear size, as observed in the rat (Baker and Abrams, '55; Sesso et al., '55). Condensation of the Golgi apparatus in pancreatic acinar cells occurs also in the rat (Baker, personal communication ).

Parotid gland. Changes in the parotid gland of the mouse after hypophysectomy are generally similar to those occurring in the rat although the loss in weight appears to be somewhat greater in the rat (Baker and Abrams, '55). Alteration in morphology of acinar mitochondria in the mouse contrasts with Dewey's ('58) negative findings in the rat. In both mouse and rat (Baker and Abrams, '55), depletion of cytoplasmic basophilia is not as great as in the gastric chief cells and pancreas. Atrophy of the salivary ducts in the hypophysectomized mouse appears more pronounced than that seen by Baker and Abrams ('55) and Dewey ('58) in the rat, but is of approximately the same magnitude as that reported by Yoshimura ('56).

Submandibular gland. The loss in weight of the submandibular gland after hypophysectomy agrees with reports for the mouse (Lacassagne and Chamorro, '40), dog (Argonz, '61), cat (Kahlson and Renvall, '56), and rat (Baker and Abrams, '55). Atrophy of the serous tubules with depletion of their zymogenic granules also seems to be a general phenomenon since it has now been observed in the mouse (Lacassagne and Chamorro, '40), rat (Sreebny et al., '57), cat (Kahlson and Renvall, '56), and dog (Argonz, '61).

Earlier workers (Lacassagne and Chamorro, '40; Gabe, '50; Taurog et al., '59) observed no acinar changes in the mouse after hypophysectomy. However, in this study, a decrease in submandibular acinar size with a loss of cytoplasmic basophilia and secretory material was observed. Somewhat similar changes were found in the rat by Baker et al. ('64), Yoshimura ('56), and in the dog by Argonz ('61). Bixler et al. ('57) reported a fall in RNA content of the acinar cells in the rat and Kronman ('63) and Baker et al. ('64) described a decrease in the PAS-staining intensity of the mucous acini of the rat. Only Sreebny et al. ('57) found pituitary removal to be without effect on submandibular acinar cells in the rat. Therefore, complete agreement does not exist but most evidence indicates that the hypophysis exerts a regulatory influence over the production of submandibular mucus.

Sublingual gland. Of all major digestive glands, the sublingual glands are affected the least by removal of the pituitary gland. Nevertheless, as in the rat (Baker and Abrams, '55), the mean absolute weight, the mean gland weight/ body weight ratio and the amount of mucin in acinar cells are decreased in the mouse. In contrast, Kronman ('63) saw no histological changes in the rat. The involution of striated ducts accompanied by increased mitochondrial concentration, and the degranulation of some ductular epithelial cells after hypophysectomy appear to be unique to the mouse.

\section{The effect of hypophysectomy on protein synthesis}

The considerable evidence now available for the rat and mouse indicates that, in general, protein-producing cells of the digestive system undergo greater atrophy after hypophysectomy than do other epithelial cell types. For the mouse, this conclusion is made evident by the structural responses of gastric chief cells, acinar cells of the pancreas and parotid glands, and serous cells in the submandibular and sublingual ducts. Biochemical data are available from study of other species to prove that this histological involution represents a true functional depression. Thus, in the rat, storage or secretion of the following enzymes is decreased after hypophysectomy: pepsin (Baker and Abrams, '54); pancreatic 
protease (Haist, '55; Baker, Reid and Thoms, '56), amylase (Barrett et al., '55), and lipase (Bicknell and Baker, '62); submandibular amylase and protease (Sreebny et al., '57); and amylase in the parotid gland (Baker, Klegman, Logan and Garner, '56).

The structural and histochemical alterations elicited in zymogenic cells by hypophysectomy, when interpreted on the basis of available biochemical data, suggest that protein synthesis is deficient in protein-secreting cells. Thus, the decrease in nucleolar size, amount of cytoplasmic basophilia, size of the Golgi apparatus, and in the number of secretory granules, all may be taken as indicators of interference at several points in the pathway of protein synthesis. Since RNA of the nucleolus is representative of rRNA (De Robertis et al., '65), reduction in size of the nucleolus after hypophysectomy may suggest that a block occurs in the formation of rRNA. The reduction in cytoplasmic basophilia after pituitary ablation reflects a reduction in RNA, although the RNA fraction that accounts for this basophilia has not been finally identified. Nevertheless, the profound loss of basophilia in chief cells and pancreatic acinar cells indicates that ribosomes are depleted from the cytoplasm, a reduction in number having been demonstrated by Corpron ('66) in chief cells of the rat. The involvement of rough-surfaced endoplasmic reticulum and ribosomes in protein synthesis has been revealed by both biochemical procedures (Korner, '59; Hultin, '64; and many others), and electron microscopy combined with radioautography (Kurosumi, '61; Caro and Palade, '64). Furthermore, a deficiency in the capacity of ribosomes to form polypeptides after hypophysectomy has been demonstrated for the liver by Korner ('59) and for the prostate gland after castration by Liao and Williams-Ashman ('62). It is probable that the ribosomes of zymogenic cells are also deficient in their proteinsynthesizing capacity in the absence of pituitary hormones.

It is currently held that polypeptides pass from ribosomes into the cisternae, through which they move to the Golgi apparatus. Here, the secretory product is enclosed by a smooth-surfaced membrane and becomes microscopically visible. A direct relationship between size of the Golgi apparatus and secretory activity has long been recognized in many types of secretory cells (Kirkman and Severinghaus, '38; Dalton, '61). Thus, contraction of the Golgi apparatus in pancreatic acinar cells of both mouse and rat after pituitary ablation indicates further that the production of protein is retarded. The depletion of secretory granules from zymogenic cells also reflects decreased production of secretion, since there is no evidence that release of secretion from the cell is accentuated by hypophysectomy.

\section{The effect of hypophysectomy on acid production and ion transport}

Production of acid by the stomach is influenced by pituitary hormones. A reduction in acid secretion and/or an elevation of $\mathrm{pH}$ occurs in the stomach of the rat (Crafts and Walker, '47; Baker and Abrams, '55), cat (Cutting et al., '37) and man (Dotevall and Westling, '63) after hypophysectomy. This effect correlates well with the decrease in size (Baker and Abrams, '54) and in total number of parietal cells (Friedman, '53; Crean, '63a,b) present after pituitary ablation of the rat and with the profound involution of parietal cells observed in the mouse.

Ion transport also occurs in the ducts of salivary glands, where cell morphology may be correlated with function. Junqueira ('64) demonstrated a relationship between the histology of the salivary ducts and ion composition of the saliva. The involution of salivary ducts which occurs in the mouse parotid and sublingual glands after pituitary removal suggests that ion transport across their epithelium is altered. On the other hand, in the submandibular gland Taurog et al. ('59) did not detect any change in the iodine-concentrating capacity of the submandibular gland of the mouse after hypophysectomy. In accord with this observation, basal striations do not disappear from the nongranulated cells in salivary ducts of the submandibular gland in the mouse. 


\section{CONCLUSIONS}

It was concluded that, as in the rat, the protein-secreting cells of the digestive tract of the mouse depend on the support of pituitary hormones. This principle appears to be applicable to other mammals as well. Also, the cells of the mouse digestive glands which secrete mucopolysaccharides or are involved in ion transport require the action of pituitary hormones for maintenance of their structure and function. The degree of dependence on pituitary stimulation varies with the type of cell and species of animal.

\section{ACKNOWLEDGMENT}

I wish to thank Professor Burton L. Baker for his direction of this research.

\section{LITERATURE CITED}

Argonz, J. J. 1961 Glandes salivaires des Chiens hypophysectomisés. C. R. Soc. Biol., 155: 165166.

Baker, B. L., and G. D. Abrams 1954 Effect of hypophysectomy on the cytology of the fundic glands of the stomach and on the secretion of pepsin. Am. J. Physiol., 177: 409-412.

1955 Growth hormone (somatotropin) and the glands of the digestive system. In: The Hypophyseal Growth Hormone, Nature and Actions. R. W. Smith, O. H. Gaebler and C. N. H. Long, eds. McGraw-Hill, New York, pp. 107122.

Baker, B. L., H. W. Clapp and J. A. Light 1964 Hormonal influences on the cytology and physiology of salivary glands. In: Salivary Glands and Their Secretions. L. M. Sreebny and J. Meyer, eds. Macmillan, New York, pp. 63-80.

Baker, B. L., and R. H. Clark 1961 Influence of hypophysectomy on oxidative enzymes and size of parietal cells in gastric mucosa. Proc. Soc. Exp. Biol. Med., 106: 65-67.

Baker, B. L., J. F. Kent and E. C. Pliske 1958 Histological response of duodenum to X-irradiation in hypophysectomized rats. Rad. Res., 9: 48-58.

Baker, B. L., J. H. Klegman, R. G. Logan and R. L. Garner 1956 Reduction in parotid amylase after hypophysectomy. Endocrinology, 59: 254-255.

Baker, B. L., N. L. Reid and N. Thoms 1956 Reduction in pancreatic proteinase after hypophysectomy. Am. J. Physiol., 186: 57-59.

Barrett, J. L., M. T. Nishikawara and R. E. Haist 1955 Effects of hypophysectomy and of undernutrition on amylolytic activity of the pancreas of the rat. Am. J. Physiol., 182: 35-38.

Bicknell, J. M., and B. L. Baker 1962 Influence of hypophysectomy on the lipolytic activity of the rat pancreas. Endocrinology, 71: 853-856.

Bixler, D., J. C. Muhler, R. C. Webster and W. G. Shafer 1957 Changes in submaxillary gland ribonucleic acid following hypophysectomy, thy- roidectomy and various hormone treatments. Proc. Soc. Exp. Biol. Med., 94: 521-524.

Caro, L. G., and G. E. Palade 1964 Protein synthesis, storage, and discharge in the pancreatic exocrine cell. J. Cell Biol., 20: 473-495.

Corpron, R. E. 1966 The ultrastructure of the gastric mucosa in normal and hypophysectomized rats. Am. J. Anat., 118: 53-89.

Crafts, R. C., and B. S. Walker 1947 The effects of hypophysectomy on gastric acidity of adult female rats. Endocrinology, 40: 395-402.

Crean, G. P. 1963a The effect of hypophysectomy on the gastric mucosa of the rat. Second World Congress of Gastroenterology, Munich, 2: 87-91.

1963b The endocrine system and the stomach. In: Vitamins and Hormones. Academic Press, New York, vol. 21, pp. 215-280.

Cutting, W. C., E. C. Dodds, R. L. Noble and P. C. Williams 1937 Pituitary control of alimentary blood flow and secretion. Gastric secretion and blood flow in hypophysectomized animals. Proc. Royal Soc., London, ser. B, 123: 49-59.

Dalton, A. J. 1961 Golgi apparatus and secretion granules. In: The Cell, vol. II. J. Brachet and A. E. Mirsky, eds. Academic Press, New York, pp. 603-620.

De Robertis, E. D. P., W. W. Nowinski and F. A. Saez 1965 Cell Biology. W. B. Saunders, Philadelphia, p. 315.

Dewey, M. M. 1958 A histochemical and biochemical study of the parotid gland in normal and hypophysectomized rats. Am. J. Anat., 102: 243-271.

Dotevall, G., and H. Westling 1963 Gastric acid secretion before and after hypophysectomy in man. Acta Med. Scand., 174: 777-780.

Falconi, G., and G. I. Rossi 1964 Transauricular hypophysectomy in rats and mice. Endocrinology, 74: 301-303.

Fekete, Elizabeth 1941 Histology. In: Biology of the Laboratory Mouse. G. D. Snell, ed. Blakiston, Philadelphia, pp. 89-167.

Friedman, M. H. F. 1953 The response of different regions of the gastrointestinal tract to normal and abnormal stimuli (influence of feeding inert bulk material and of hypophysectomy). J. Nat. Cancer Inst., 13: 1035-1038.

Gabe, M. 1950 Action de la thyroxine sur la glande sous-maxillaire du Rat hypophysectomisé. C. R. Acad. Sci., 230: 1317-1318.

Haeger, K., D. Jacobsohn and G. Kahlson 1953 Atrophy of the gastrointestinal mucosa following hypophysectomy or adrenalectomy. Acta Physiol. Scand., 30 (suppl. 111): 161-169.

Haist, R. E. 1955 The influence of growth hormone and other factors on the islets of Langerhans and the pancreas. In: The Hypophyseal Growth Hormone, Nature and Actions. R. W. Smith, O. H. Gaebler and C. N. H. Long, eds. McGraw-Hill, New York, pp. 437-447.

Helander, H. F. 1962 Ultrastructure of fundus glands of the mouse gastric mucosa. J. Ultrastructure Res., suppl. 4: 1-123.

1964 Ultrastructure of gastric glands of refed mice. J. Ultrastructure Res., 10: 160-175. 
Hotchkiss, R. D. 1948 A microchemical reaction resulting in the staining of polysaccharide structures in fixed tissue preparations. Arch. Biochem., 16: 131-141.

Hultin, T. 1964 Ribosomal functions related to protein synthesis. In: International Review of Cytology, vol. 16. G. H. Bourne and J. F. Danielli, eds. Academic Press, New York, pp. 1-36.

Ito, S. 1961 The endoplasmic reticulum of gastric parietal cells. J. Biophys. Biochem. Cytol., 11: 333-347.

Ito, S., and R. J. Winchester 1963 The fine structure of the gastric mucosa in the bat. J. Cell Biol., 16: 541-577.

Junqueira, L. C. U. 1964 Studies on the physiology of rat and mouse submaxillary glands. III. On the function of the striated ducts of the mammalian salivary glands. In: Salivary Glands and Their Secretions. L. M. Sreebny and J. Meyer, eds. Macmillan, New York, pp. 123-128.

Junqueira, L. C., A. Fajer, M. Rabinovitch and L. Frankenthal 1949 Biochemical and histochemical observations on the sexual dimorphism of mice submaxillary glands. J. Cell. Comp. Physiol., 34: 129-158.

Kahlson, G., and S. Renvall 1956 Atrophy of salivary gland following adrenalectomy or hypophysectomy and the effect of DOCA in cats. Acta Physiol. Scand., 37: 150-158.

Kirkman, H., and A. E. Severinghaus 1938 A review of the Golgi apparatus. Part III. Anat. Rec., 71: 79-104.

Korner, A. 1959 The effect of hypophysectomy of the rat and of treatment with growth hormone on the incorporation of amino acids into liver proteins in a cell-free system. Biochem. J., 73: $61-71$.

Koster, S. 1930 Experimentelle Untersuchung der Hypophysenfunktion beim Hunde. Pflüg. Arch. f. Physiol., 224: 212-216.

Kronman, J. H. 1963 A histochemical study of hypophysectomy-induced changes in rat submandibular and sublingual glands. Am. J. Anat., 113: 337-345.

Kurosumi, K. 1961 Electron microscopic analysis of the secretion mechanism. In: International Review of Cytology, vol, 11. G. H. Bourne and J. F. Danielli, eds. Academic Press, New York, pp, 1-124.

Lacassagne, A. 1940 Dimorphisme sexuel de la glande sous-maxillaire chez la Souris. C. R. Soc. Biol., 133: 180-181.

Lacassagne, A., and A. Chamorro 1940 Réaction a la testostérone de la glande sous-maxillaire atrophiée consécutivement a l'hypophysectomie chez la Souris. C. R. Soc. Biol., 134: 223224.

Laumonier, R., C. Faye, E. Martin, J. P. Hardouin and Ch. Debray 1963 La muqueuse gastrique au cours des maladies endocriniennes. Etude gastro-biopsique et expérimentale. Arch. Anat. Pathol., 11: 55-66.

Liao, S., and H. G. Williams-Ashman 1962 An effect of testosterone on amino acid incorporation by prostatic ribonucleoprotein particles. Proc. Nat. Acad. Sci., U. S., 48: 1956-1964.
Lillibridge, C. B. 1964 The fine structure of normal human gastric mucosa. Gastroenterology, 47: 269-290.

Mowry, R. W. 1958 Improved procedure for the staining of acidic polysaccharides by Müller's colloidal (hydrous) ferric oxide and its combination with the Feulgen and periodic acidSchiff reactions. Lab. Invest., 7: 566-576.

Parks, H. F. 1961 On the fine structure of the parotid gland of mouse and rat. Am. J. Anat., 108: 303-329,

Raynaud, J. 1960 Contrôle hormonal de la glande sous-maxillaire de la Souris. Bull. Biol. de France et Belgique, 94: 400-524.

Rinehart, J. F, and S. K. Abul-Haj 1951 Improved method of histological demonstration of acid mucopolysaccharides in tissues. Arch. Path., 52: 189-194.

Robert, A., J. P. Phillips and J. E. Nezamis 1966 Gastric secretion and ulcer formation after hypophysectomy and administration of somatotrophic hormone. Am. J. Dig. Dis., 11: 546-552.

Schätzle, W. 1962 Histochemie der Speicheldrüsen. Acta Histochem., 13: 62-112.

Schooley, J. P., O. Riddle and R. W. Bates 1941 Replacement therapy in hypophysectomized juvenile pigeons. Am. J. Anat., 69: 123-158.

Sedar, A. W. 1965 Fine structure of the stimulated oxyntic cell. Fed. Proc., 24: 1360-1367.

Sedar, A. W., and M. H. F. Friedman 1961 Correlation of the fine structure of gastric parietal cell (dog) with functional activity of the stomach. J. Biophys. Biochem. Cytol., 11: 349-364.

Sesso, A., J. H. Tramezzani, V. Valeri and R. H. Migliorini 1955 Action de l'hypophysectomie sur les acides nucléiques et l'activité secrétoire du pancréas du Rat, d'après des études biochimiques et cytologiques. C. R. Acad. Sci., 241: 775-777.

Severinghaus, A. E., and K. W. Thompson 1939 Cytological changes induced in the hypophysis by prolonged administration of pituitary extract. Am. J. Path., 15: 391-412.

Shafer, W. G., and J. C. Muhler 1960 Endocrine influences upon the salivary glands. Ann. N. Y. Acad. Sci., 98: 215-227.

Spicer, S. S. 1960 A correlative study of the histochemical properties of rodent acid mucopolysaccharides. J. Histochem. Cytochem., 8: 18-36.

Spicer, S. S., and M. H. Jarrels 1961 Histochemical reaction of an aromatic diamine with acid groups and periodate engendered aldehydes in mucopolysaccharides. J. Histochem. Cytochem., 9: 368-379.

Sreebny, L. M., J. Meyer, E. Bachem and J. P. Weinmann 1957 Restoration of enzymatic activity in the submaxillary gland of the hypophysectomized albino rat. Endocrinology, 60: 200-204.

Steel, R. G. D., and J. H. Torrie 1960 Principles and Procedures of Statistics. McGraw-Hill, New York.

Taurog, A., G. D. Potter and I. L. Chaikoff 1959 The effect of hypophysectomy and of TSH on the mouse submaxillary iodide pump. Endocrinology, 64: 1038-1051. 
Vial, J. D., and H. Orrego 1960 Electron microscope observations on the fine structure of parietal cells. J. Biophys. Biochem. Cytol., 7: 367372.
Yoshimura, F. 1956 Cytological changes in rat salivary glands following hypophysectomy and somatotrophic hormone administration. Okajimas Folia Anat. Jap., 28: 195-205.

\section{PLATE 1}

EXPLANATION OF FIGURES

Figures 1 and 2: fixed in FAA, stained with PAS-azure II, $4 \mu, \times 100$. Figures 3 and 4: fixed in FAA, stained with colloidal iron-PAS, $4 \mu, \times 1000$.

1 Gastric mucosa of a pair-fed control mouse. Chief cells (C) are columnar and have basally located cytoplasmic basophilia and a granule-filled apex. They are found in the lower one-third of the mucosa. Parietal cells (P) are primarily located in the middle one-third of the mucosa, as well as being scattered in the neck and base of the fundic glands. Mucous neck cells (arrow) are interposed among parietal cells in the area just superficial to the chief cells. Mucous surface cells extend from the gastric pits (GP) onto the surface.

2 Gastric mucosa of a mouse, 70 days after hypophysectomy. As compared with figure 1 , the mucosa is thinner. Chief cells (C) appear to be decreased in number and size and have fewer granules and less cytoplasmic basophilia. Parietal cells (P) are smaller. Mucous neck cells (arrow) appear more numerous. Mucous surface cells are unchanged. The lumina of the fundic glands are dilated.

3 Gastric mucosa of an ad libitum-fed control mouse. Three histochemically different varieties of mucous neck cells are shown. Colloidal iron-positive mucous neck cells (a) stain darkly with colloidal iron (black). PAS-positive mucous neck cells (b) are lightly stained with PAS (grey). A transition phase is shown in which PAS-positive mucous neck cells contain colloidal iron-positive granules (arrow). Parietal cells (P) are large.

4 Gastric mucosa of a mouse, 70 days after hypophysectomy. As compared with figure 3 , the total number of mucous neck cells appears to be increased per fundic gland. Only the colloidal iron-positive mucous neck cells (black) are present. The lumina of the fundic glands are dilated (arrow). Parietal cells (P) are reduced in size. 


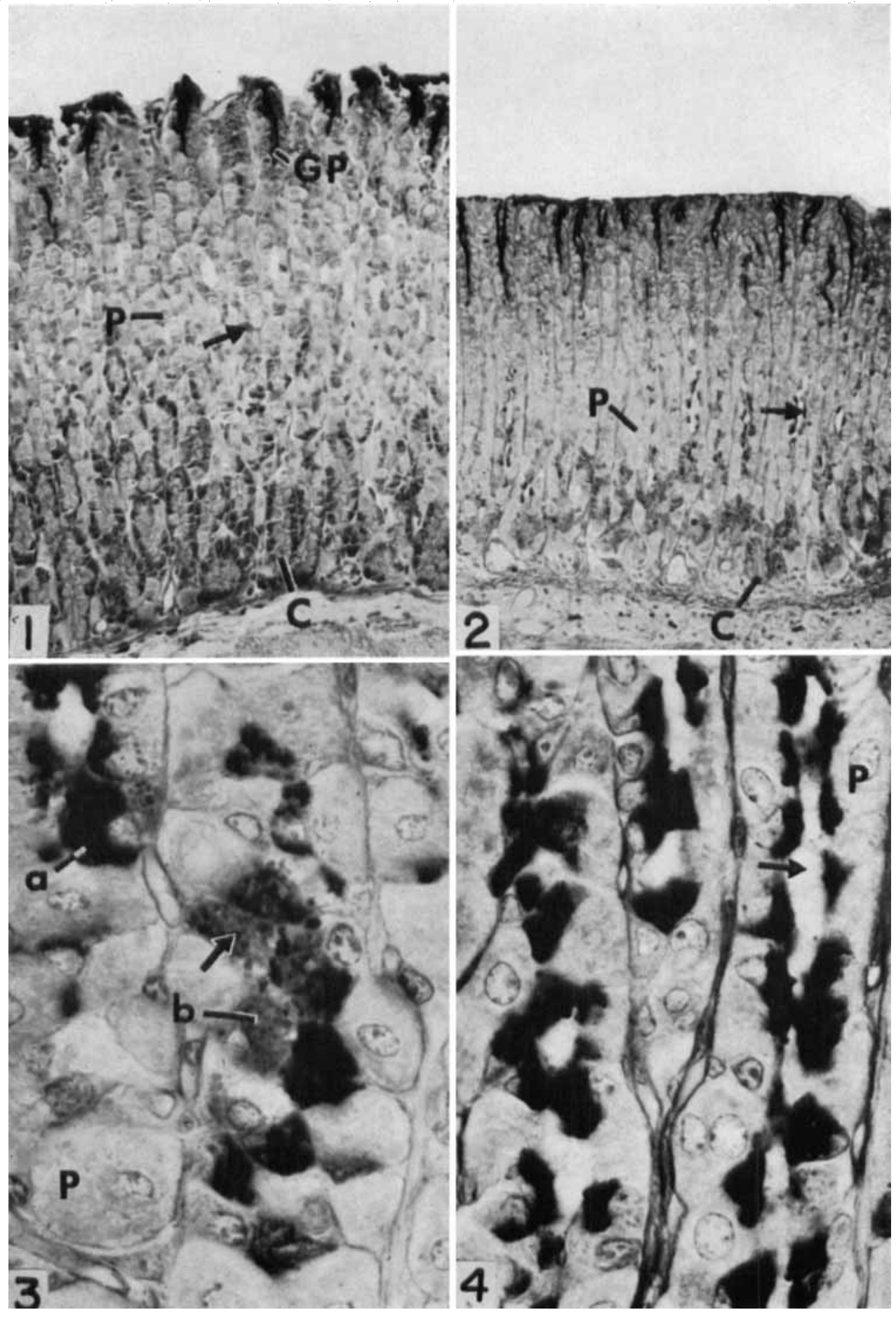


PLATE 2

EXPLANATION OF FIGURES

Figures 5 and 6: fixed in FAA, stained with PAS-azure II, $4 \mu, \times 1000$. Figures 7, 8, 9 and 10: fixed in Regaud's fluid, stained with Altmann-Masson, $3 \mu, \times 1550$.

5 Gastric mucosa of an ad libitum-fed control mouse. The parietal cells are Iarge and have large nuclei with prominent nucleoli and sparse chromatin. A perinuclear halo of PAS-positive material (arrow) indicates the position of the intracellular canaliculi which cup around the nucleus from the luminal side.

6 Gastric mucosa of a mouse, 68 days after hypophysectomy. The parietal cells (P) are smaller and have smaller nuclei and nucleoli and coarsely clumped chromatin. No halos of PAS-positive material are present but clumps of PAS-positive material are found on the luminal side of the nucleus (arrow). The fundic lumina are dilated as compared with the control (fig. 5).

7 Gastric mucosa of an ad libitum-fed control mouse. The parietal cells (P) are large and have large rounded mitochondria (M) located along the cell and nuclear membranes. The area (arrow) between the two rows of mitochondria indicates the location of the cup-shaped intracellular canaliculi and corresponds with the PAS-positive perinuclear halo (fig. 5).

8 Gastric mucosa of a mouse 86 days after hypophysectomy. The parietal cells (P) are smaller. The intracellular canaliculi do not cup around the nucleus, being limited to the luminal area of the cell. The luminal openings of the canaliculi are dilated (arrow). Mitochondria (M) are reduced in number and tend to be arranged around the basal aspect of the nucleus in a cup-like formation. The glandular lumen ( $L$ ) is dilated as compared with that of the control (fig. 7).

9 Gastric mucosa of a pair-fed control mouse. Chief cells are illustrated. Their apical portions are filled with large secretory granules (G). The mitochondria (arrow) are long and thread-like and are located predominantly basal and lateral to the nucleus (N).

10 Gastric mucosa of a mouse, 68 days after hypophysectomy. Chief cells are illustrated. Their secretory granules are sparse. Mitochondria (arrow) are shorter and wider than in the control (fig. 9). Their arrangement follows the contour of the nucleus (N). 


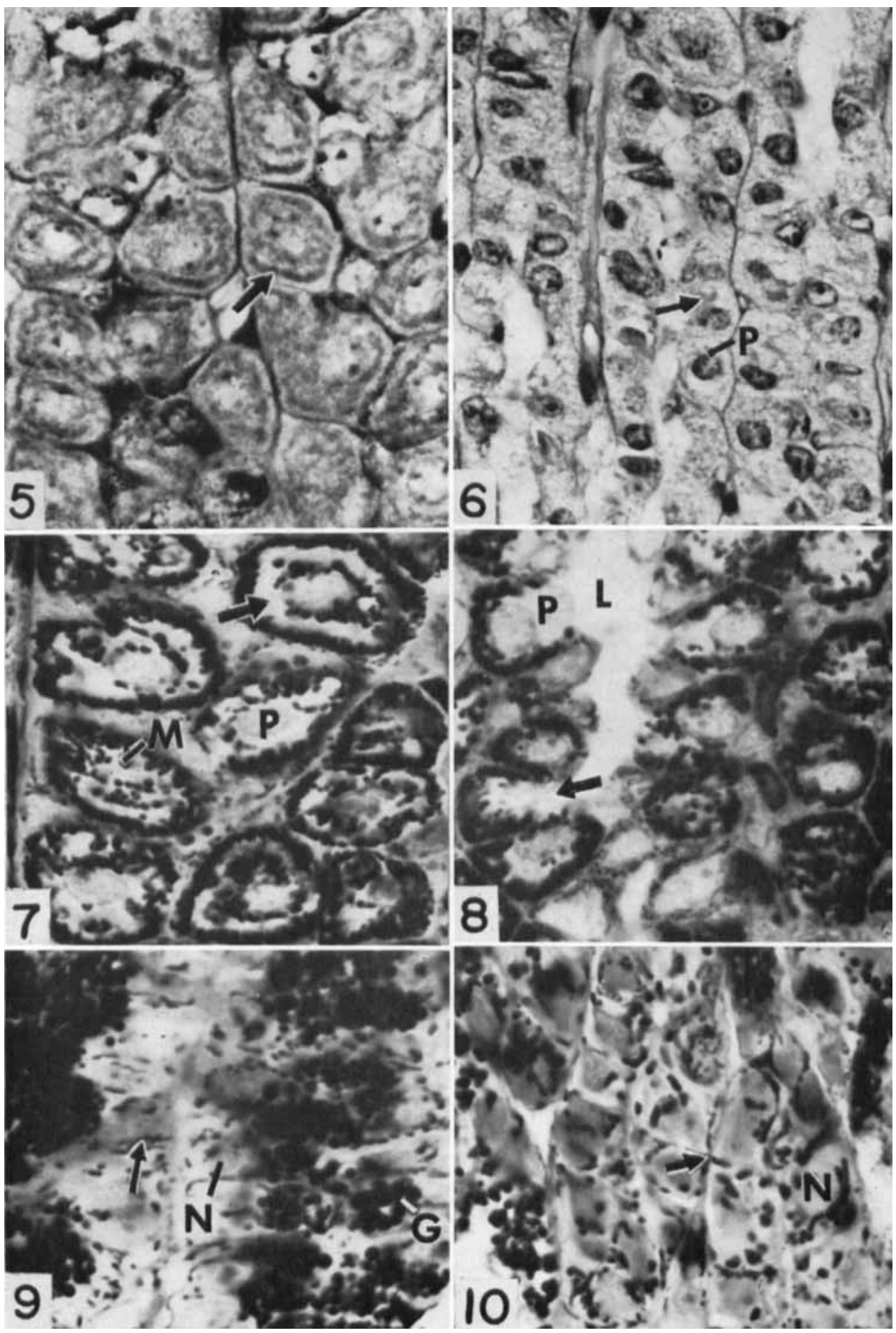




\section{PLATE 3}

EXPLANATION OF FIGURES

Figures 11 and 12: fixed in FAA, stained with PAS-azure II, $4 \mu, \times 1000$. Figures 13 and 14: fixed in Zenker-formol, stained with azure II-phloxine, $3 \mu, \times 600$.

11 Gastric mucosa of a pair-fed control mouse. The chief cells (C) are columnar. The cytoplasmic basophilia (E) is dense basally and basophilic material is sparsely distributed among the secretory granules. Secretory granules (G) are not fixed but the distribution of vacuoles shows that they filled the apex of the cell. The nuclei have prominent nucleoli (arrow) and fine chromatin.

12 Gastric mucosa of a mouse, 68 days after hypophysectomy. The chief cells are low cuboidal. The cytoplasmic basophilia (E) is reduced to smaller areas around the nucleus. Almost no secretory granules are present. The nuclei are smaller, the chromatin coarser and the nucleoli (arrow) smaller as compared with the control (fig. 11).

13 Pancreatic acinar cells from a pair-fed control mouse. The pancreatic cells are large and filled with granules (G). The cytoplasmic basophilia ( $E$ ) is abundant basally and distributed as a fine network among the apical secretory granules. The nuclei have prominent nucleoli (arrow).

14 Pancreatic acinar cells from a mouse, 57 days after hypophysectomy. The acini and acinar cells are reduced in size and have fewer secretory granules (G) as compared with the control (fig. 13). The cytoplasmic basophilia (E) is reduced in total amount and staining intensity. The nuclei have more compact chromatin and smaller nucleoli (arrow). 

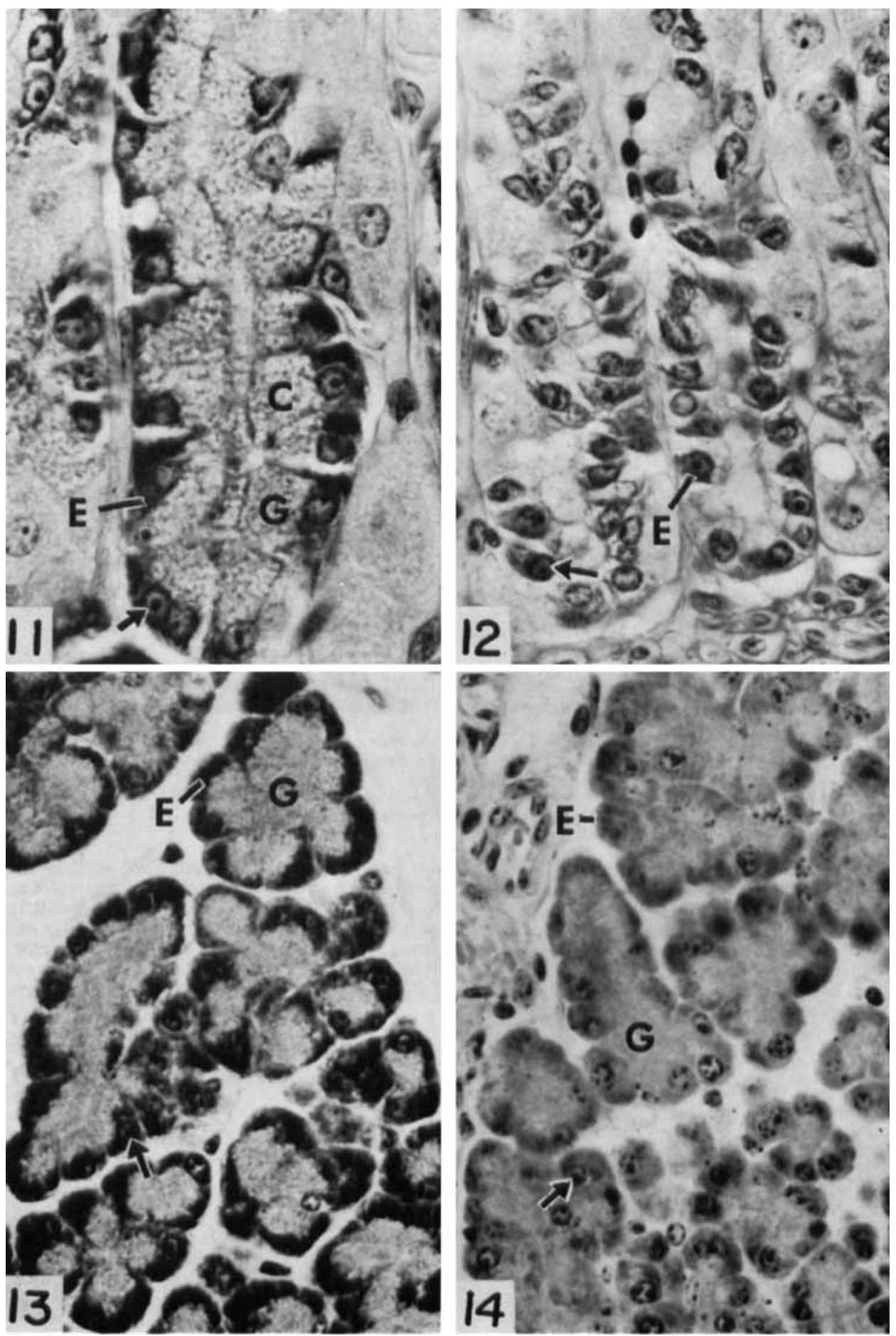


\section{PLATE 4}

\section{EXPLANATION OF FIGURES}

Figures 15 and 16: fixed with Zenker-formol, stained with Altmann-Masson, $3 \mu, \times 1700$. Figures 17 and 18: fixed with Champy's fluid, post-osmicated, $3 \mu, \times 1000$. Figures 19, 20 and 21: fixed with Zenker-formol, stained with Altmann-Masson, $3 \mu, \times 1000$.

15 Pancreatic acinar cells from a pair-fed control mouse. The mitochondria (arrow) are long string-like structures in the basal area and extend to the secretory granules (G) in the apex of the cells.

16 Pancreatic acinar cells from a mouse, 73 days after hypophysectomy. The mitochondria (arrow) are shorter and finer than those of the control (fig. 15). They often follow the curvature of the nucleus and are located basal, lateral and apical to it. Fewer secretory granules (G) are present.

17 Pancreatic acinar cells from an ad libitum-fed control mouse. The Golgi apparatus (arrow) is distributed throughout most of the supranuclear region of the cell among the secretory granules.

18 Pancreatic acinar cells from a mouse, 86 days after hypophysectomy. The Golgi apparatus (arrow) is smaller and more compact than that in the control (fig. 17).

19 Parotid acinar cells from a pair-fed control mouse. The acinar cells are filled with granules (G). Mitochondria (arrow) are rod-like and randomly oriented.

20 Parotid salivary ducts from a pair-fed control mouse. Mitochondria (arrow) are primarily located basal to the nucleus paralleling the basal striations (B). A few mitochondria are present apical to the nucleus.

21 Parotid gland from a mouse, 71 days after hypophysectomy. The acini are smaller with fewer granules (G). The acinar mitochondria (arrow) appear more numerous than those in the control (fig. 19) due to the loss of granules. They are located around the nucleus and are thinner. The salivary ducts (SD) are smaller in diameter and their cells are lower and narrower as compared with those of the control (fig. 20). Basal striations are absent. Nuclei are smaller. Mitochondria of the salivary duct (SD) are more con. centrated, smaller and randomly oriented. They are found around the nucleus as well as basal to it. 


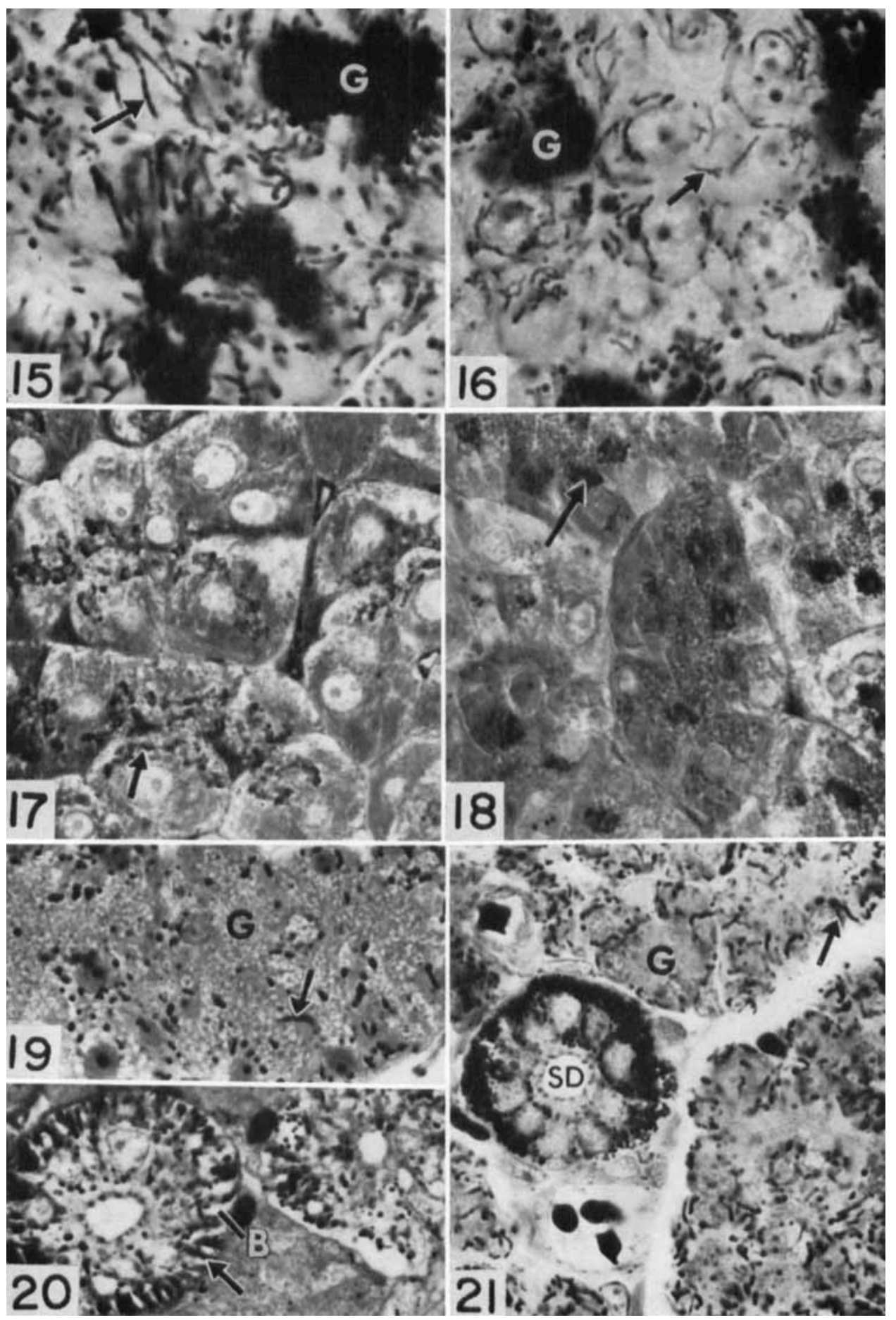


PLATE 5

EXPLANATION OF FIGURES

Figures 22 and 23: fixed in FAA, stained with PAS-azure II, $5 \mu, \times 400$. Figures 24 and 25: fixed in FAA, stained with PAS-azure II, $5 \mu, \times 925$.

22 Parotid gland of a pair-fed control mouse. The acinar cells have dense basal cytoplasmic basophilia (E) and are filled with secretory granules (G). Intercalated ducts (I) are seen. The salivary ducts (SD) are lined by columnar cells with prominent basal striations (B).

23 Parotid gland of a mouse, 71 days after hypophysectomy. The acinar diameters are smaller than those of the control (fig. 22). Intercalated ducts (I) are not greatly changed. They appear prominent because of the acinar involution.

24 Parotid gland of a pair-fed control mouse. The acinar cells have basally located cytoplasmic basophilia (E) which extends as a fine network (arrow) among the granules (G). The salivary ducts (SD) have basal striations (B).

25 Parotid gland of a mouse, 71 days after hypophysectomy. The acinar cells have fewer secretory granules (G) and less cytoplasmic basophilia (E). The salivary ducts (SD) are smaller and lined by low cuboidal cells. Cells of the salivary ducts have lost their basal striations and have smaller nuclei. 


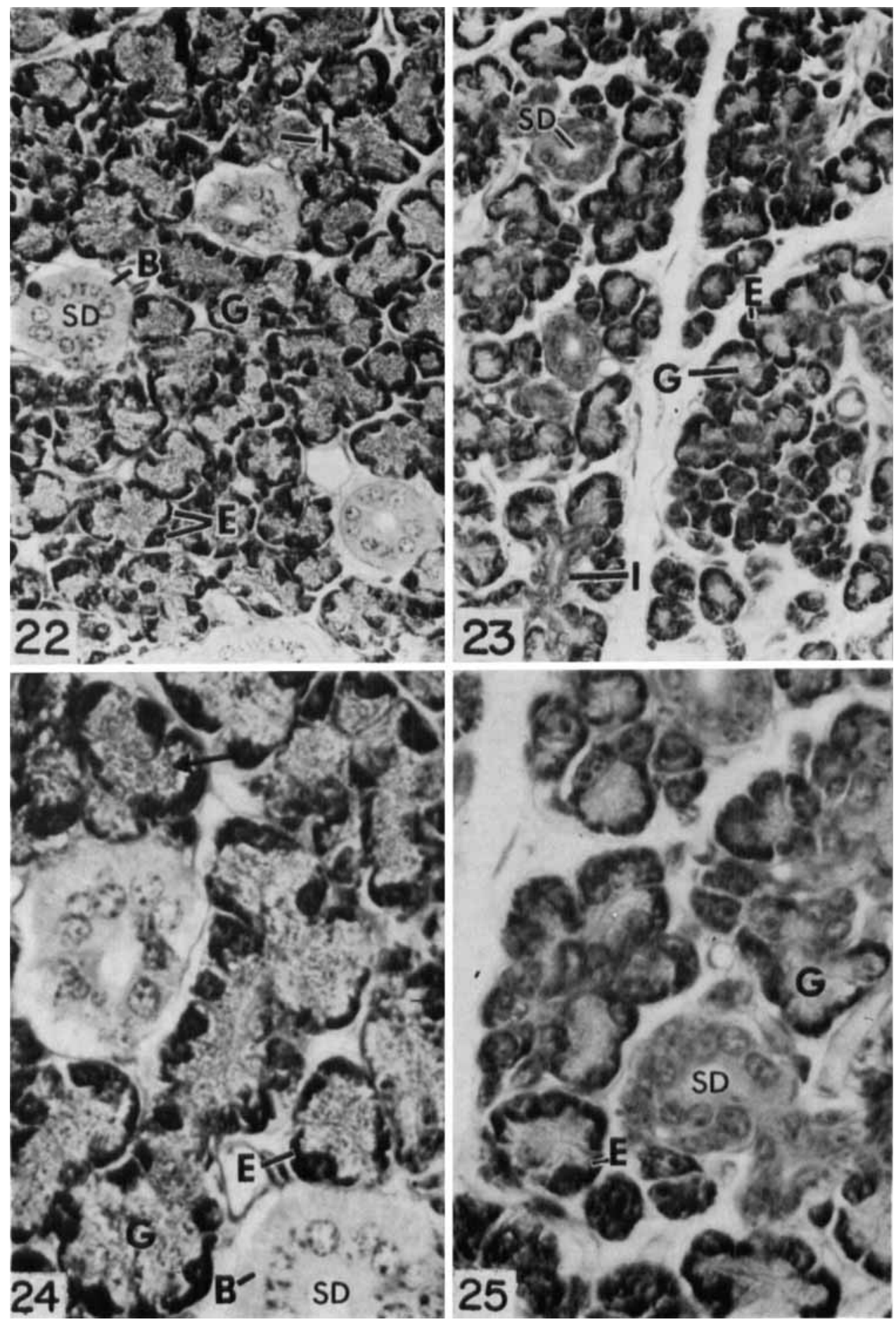


PLATE 6

EXPLANATION OF FIGURES

Figures 26 and 27: fixed in FAA, stained with colloidal iron-PAS, $5 \mu, \times 400$. Figures 28 and 29: fixed in FAA, stained with PAS-azure II, $5 \mu, \times 400$.

26 Submandibular gland of a pair-fed control mouse. Mucous acini are filled with secretory material (S) which stains intensely with colloidal iron. Epithelial cells of serous tubules are charged with secretory granules (G),

27 Submandibular gland of a mouse, 71 days after hypophysectomy. The mucous acini are smaller and contain less secretory material. The secretory material (S) stains less intensely with colloidal iron as compared with that of the control (fig. 26). Serous tubules are profoundly atrophied (arrow).

28 Submandibular gland from a pair-fed control mouse. The serous tubular cells are filled with granules (G) and possess minimal basal cytoplasmic basophilia (E) (inset). Mucous acinar cells are filled with secretory material (S) (inset) and have dense basal cytoplasmic basophilia ( $E^{\prime}$ ) (inset).

29 Submandibular gland of a mouse, 57 days after hypophysectomy. The serous tubules are atrophied with loss of granules and cytoplasmic basophilia. The mucous acini are smaller and possess less secretory material (S) (inset) and somewhat less cytoplasmic basophilia (E) (inset) as compared with the control (fig. 28 , inset). Cells of the serous tubules appear to contain more PAS-positive granules (arrow) than those in the control (fig. 28). 

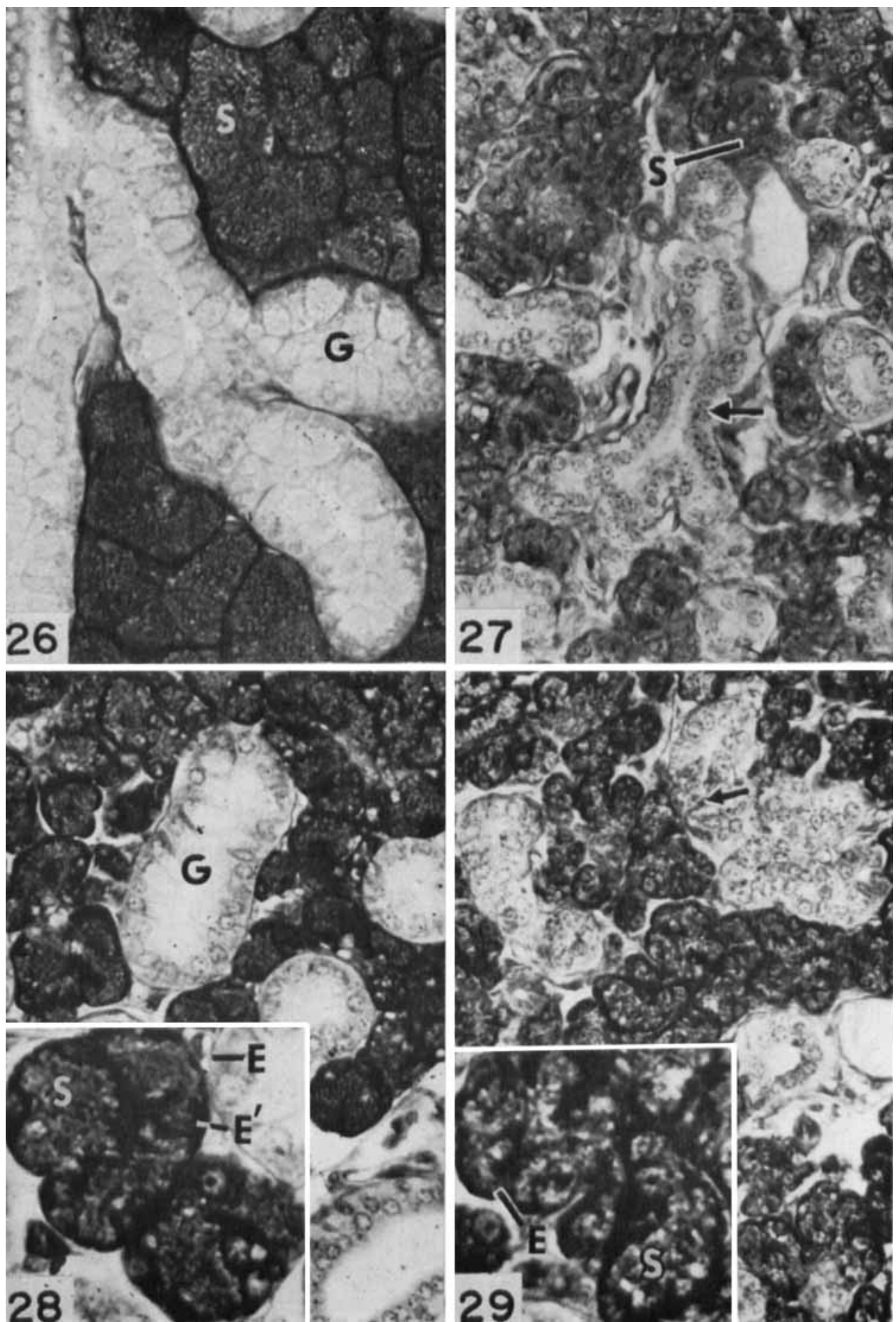


\section{PLATE 7}

EXPLANATION OF FIGURES

Figures 30 and 31: fixed in Zenker-formol, stained with Altmann-Masson, $3 \mu$, $\times$ 1000. Figures 32 and 33: fixed in FAA, stained with colloidal iron-PAS, $5 \mu, \times 400$.

30 Submandibular gland from an ad libitum-fed control mouse. Mitochondria of the serous tubular cells (arrow) are small, randomly oriented and located chiefly in the basal half of the cells. Serous tubular cells are filled with granules $(G)$.

31 Submandibular gland from a mouse, 68 days after hypophysectomy. The serous tubules (ST) are atrophied and depleted of granules. Nuclei of the serous tubular cells are smaller as compared with those of the control (fig. 30). Mitochondria (arrow) tend to be wider as compared with those of the control (fig. 30). Some mitochondria are oriented Ferpendicularly to the base of the cell.

32 Sublingual gland from a pair-fed control mouse. The mucous acini are filled with secretory material (S). The salivary duct (SD) is lined with high columnar epithelium. An intercalated duct (arrow) is shown.

33 Sublingual gland from a mouse, 68 days after hypophysectomy. The mucous acini are smaller and have less secretory material (S). Cells of the salivary duct (SD) are involuted as compared with the control (fig. 32). Intercalated ducts are not involuted (arrow). 

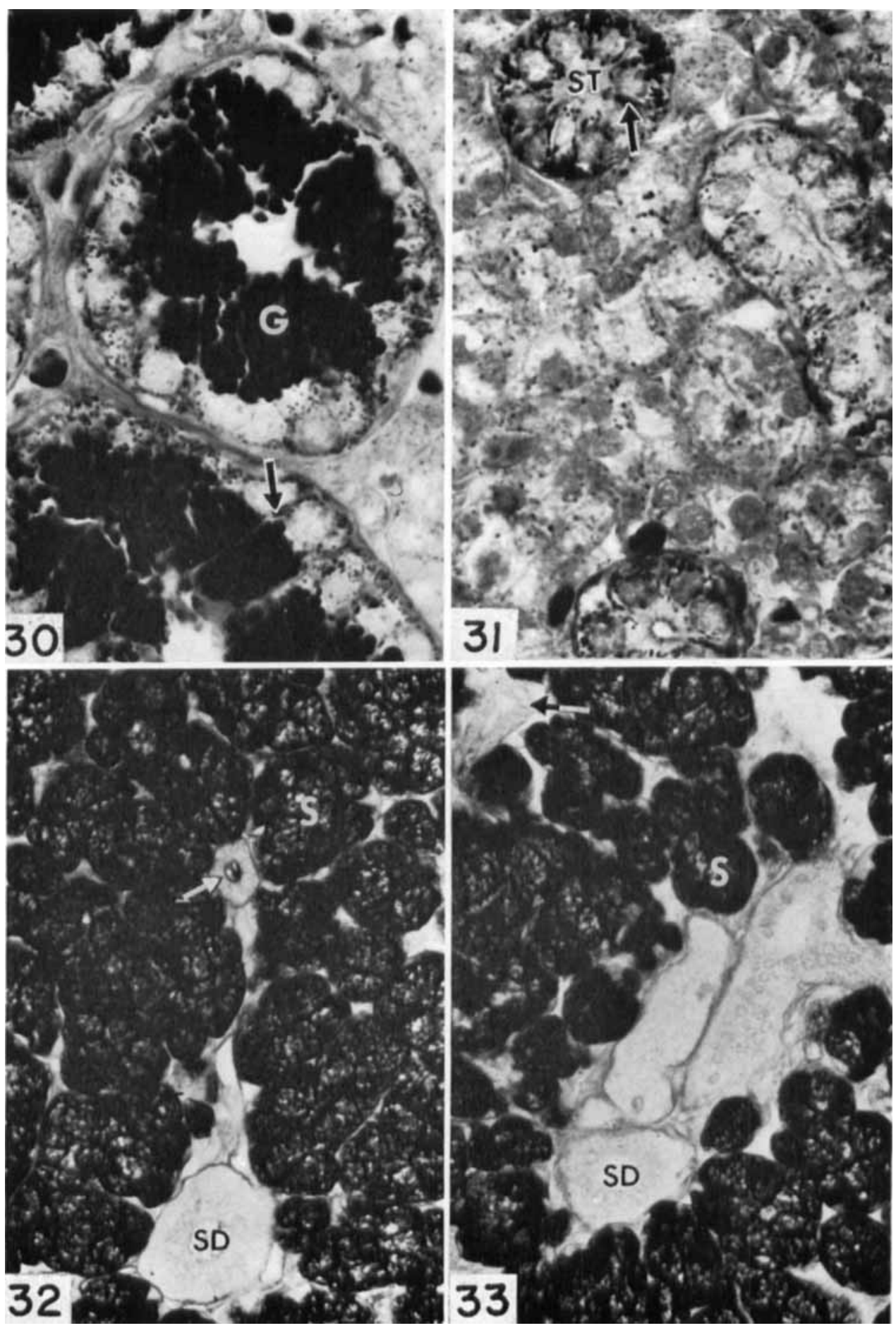


\section{PLATE 8}

EXPLANATION OF FIGURES

Figures 34 and 35: fixed in Zenker-formol, stained with colloidal iron-PAS, $3 \mu$, $\times 1000$. Figures 36 and 37: fixed in FAA, stained with colloidal iron-PAS, $5 \mu$, $\times 2062$.

34 Sublingual gland of an ad libitum-fed control mouse. Mitochondria (arrow) of salivary duct (SD) cells are concentrated basally, paralleling the basal striations. Scattered granulated cells (G) are present in the ducts. Mucous acini (A) are illustrated.

35 Sublingual gland of a mouse, 87 days after hypophysectomy. Cells of salivary ducts (SD) are smaller, with less prominent basal striations and smaller nuclei. The mitochondria (arrow) are more concentrated, randomly arranged in the basal area and smaller than the control (fig. 34). No granulated cells are present. $\mathrm{Mu}-$ cous acini (A) are smaller.

36 Salivary duct in the sublingual gland of a pair-fed control mouse. The duct cells have large nuclei and considerable material in the infranuclear region which stains with colloidal iron (arrow).

37 Salivary duct of a sublingual gland of a mouse, 68 days after hypophysectomy. The duct cells are lower, have smaller nuclei and less infranuclear cytoplasmic material which stains with colloidal iron. Some vacuoles (V) are present in the basal area. 

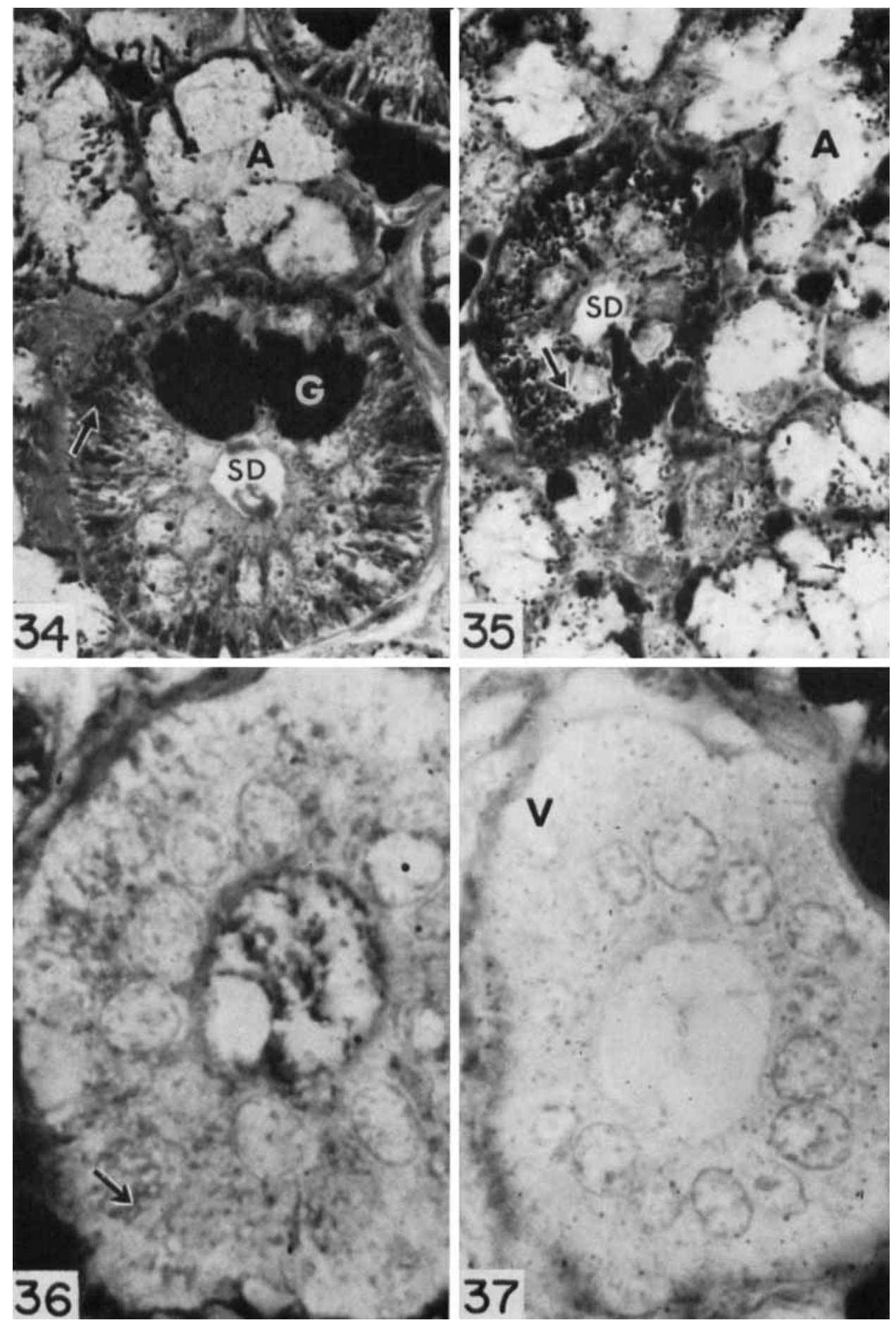